\title{
Arti Penting Ruang Hijau Kota bagi Masyarakat dan Pemerintah Kota (Ruang Hijau Kota di Lyon, Prancis)
}

\author{
Bima Fitriandana ${ }^{1}$, Laurette Wittner ${ }^{2}$, Joesron Alie Syahbana ${ }^{3}$
}

Diterima : 2 September 2014

Disetujui : 17 September 2014

\begin{abstract}
The appearance of different urban green space phenomena occuring both in developing and developed countries appeals to be found out in research. Urban green space hasn't been an essential element in developing countries, such as in Indonesia and its big city. In another part, precisely in Lyon, urban green space is considered as an intergral and important part of city development, particularly in last 24 years (begun in 1990's). Moreover, their people actively participate in some urban green space projects and go frequently in urban green spaces or urban parks. By indentifying those two phenomena, it's vividly seen a problem both in societal and municipal level. Based on those facts, this research tried to find out a research question which is about the importance of urban green space for society and minicipality. This research that has been conducted in Tête d'Or park, gerland park, Sergent Blandan park, the river bank of Saône and Rhône as well as Mazagran park, used qualitative methode with some interviews reserved to some key actors, including society. The result shows that society regards urban green space as a source of benefit for social, education and health. Whereas, municipality considers it as an integral element of city providing environmental and economic benefit for city.
\end{abstract}

Key words : urban green space, participation, society, municipality, park, importance

\section{ABSTRAK}

Adanya fenomena yang berbeda di negara berkembang dan negara maju menyangkut ruang hijau kota menjadi daya tarik utama penelitian ini. Ruang hijau kota belum menjadi suatu elemen penting di negara-negara berkembang, seperti di Indonesia, khususnya di kota Jakarta.. Di belahan dunia lain, tepatnya di Lyon, Prancis, keberadaan ruang hijau kota sangat diperhatikan, khususnya pada 24 tahun belakangan (di mulai pada tahun 1990an) dan juga dalam prosesnya, partisipasi masyarakat pun tinggi, seperti yang terjadi di proyek taman kota Mazagran dengan tingkat partisipasi masyarakat yang tinggi. Dari kedua fenomena tersebut, ada jelas permasalahan yang terjadi baik di tingkat pemerintah maupun di tingkat masyarakat. Muncul kemudian pertanyaan penelitian mengenai arti penting ruang hijau kota Lyon bagi masyarakat dan juga pemerintah kota Lyon. Penelitian ini menggunakan metode penelitian kualitatif dengan bantuan wawancara yang ditujukan kepada beberapa aktor kunci pemerintah dan juga beberapa masyarakat. Penelitian ini dilakukan di taman Tête d'Or, taman Gerland, taman Sergent Blandan, ruang hijau kota tepi sungai Saône dan Rhône serta taman kecil Mazagran. Hasil penelitian ini mengungkapkan bahwa masyarakat kota Lyon menganggap bahwa ruang hijau kota Lyon memberikan banyak manfaat untuk kehidupan mereka, terutama manfaat sosial, pendidikan dan kesehatan. Sementara bagi pemerintah, ruang hijau kota sangat berkontribusi bagi perkembangan kota mereka yang ditinjau dari dimensi lingkungan dan ekonomi kota.

Kata kunci : ruang hijau kota, partisipasi, masyarakat, pemerintah kota, taman

\footnotetext{
${ }^{1}$ Mahasiswa Magister Pembangunan Wilayah dan Kota, Undip, Semarang, Jawa Tengah

2 Dosen Ecole Nationale des Travaux Publics de l'Etat (ENTPE), Lyon 2, Perancis

${ }^{3}$ Dosen Jurusan Perencanaan Wilayah dan Kota, Undip, Semarang, Jawa Tengah

Kontak Penulis : bima_fitriandana@yahoo.com
} 


\section{PENDAHULUAN}

Pada akhir tahun 1990, fokus di bidang lingkungan muncul, khususnya mengenai kapasitas lingkungan dalam mendukung kelangsungan hidup di dunia dan juga ketergantungan pembangunan yang terus menerus muncul yang mengedepankan kemajuan sektor ekonomi. Penurunan kualitas lingkungan tidak dapat dihindarkan pada saat itu. Permasalahan ini memicu perhatian ahli-ahli dan juga aktor-aktor dunia untuk berfikir bagaimana menyelesaikan permasalahan ini. Kemudian pada tahun 1992, diselenggarakan sebuah konferensi di Rio de Janeiro, Brasil. Konferensi tersebut merupakan suatu permulaan dan merupakan suatu kelahiran konsep baru pembangunan dunia, yaitu konsep Sustainable Development/pembangunan berkelanjutan.

Menurut Chiesura, terdapat suatu hubungan antara ruang terbuka hijau kota dengan konsep tersebut. Untuk merealisasikan konsep kota berkelanjutan, ruang terbuka hijau perkotaan dapat menjadi salah satu elemen pentingnya. Bahkan dia membangun sebuah hubungan langsung antara taman kota dan kota berkelanjutan. Keberadaan pepohonan dan taman menawarkan berbagai keuntungan untuk kota, lingkungan dan masyarakat kota.

Meskipun terlihat bahwa ruang terbuka hijau menawarkan berbagai manfaat, tetapi keberadaan ruang terbuka hijau, khususnya di negara berkembang, belum diperhatikan secara mendalam. Terbukti dengan adanya tren yang menurun dan jarang ditemuinya ruang hijau perkotaan, khususnya di Indonesia. Pada tahun 2010, hanya terdapat 9,8\% ruang hijau perkotaan di Jakarta dan menurut data, hanya terdapat kenaikan sebesar 0,8\% ruang hijau perkotaan selama 10 tahun terakhir (2000-2010). Di Jakarta, terjadi pula pengalihfungsian penggunaan lahan dari fungsi taman menjadi fungsi-fungsi komersial.

Permasalahan-permasalahan ruang hijau kota di Jakarta memang komplek, tetapi hal tersebut tidak menutup kemungkinan untuk adanya perbaikan kualitas ruang hijau kota. Untuk itu, peneliti tertarik untuk mendalami penciptaan ruang hijau kota/taman kota yang berada di Lyon. Hal tersebut mengingat bahwa Lyon pada awal tahun 1970 hingga 1990 memiliki permasalahan yang sama mengenai ruang hijau perkotaan, terutama mengenai kurang dipertimbangkannya ruang hijau di lingkungan perkotaan. Lyon merupakan sebuah kota yang sedang berusaha untuk mengimplementasikan konsep kota berkelanjutan. Lyon memiliki sekitar 6 taman kota yang memiliki luas lebih dari $10 \mathrm{Ha}$ : le parc de la Tête d'Or, de Sergent Blandan, de Gerland, de Feysinne, des Hauteurs et de berges de Saône.

\section{METODE PENELITIAN}

Metode penelitian yang digunakan adalah metode kualitatif dengan wawancara semi-direktif pada aktor kunci penelitian, asosiasi dan masyarakat/pengguna sebagai alat utama penelitian. Wawancara dilakukan langsung oleh peneliti kepada: aktor pemerintah kota Lyon; Daniel Boulens (direktur bagian ruang hijau perkotaan kota Lyon) dan Julien Singer (Perwakilan dari Allain Giordano, penanggung jawab bagian ruang hijau). Kemudian melakukan wawancara dengan Lionel Perrin (penanggung jawab asosiasi Brind'Guille, asosiasi yang bertanggung jawab secara langsung pada proyek penataan kembali ruang hijau kota l'îlot Mazagran) dan dengan 20 masyarakat dan pengguna ruang hijau perkotaan. 
Untuk menjawab pertanyaan penelitian, terdapat beberapa langkah yang telah dilakukan : preobservasi lokasi penelitian, pengumpulan informasi dan data: menganalisa dokumen, observasi lapangan, wawancara dengan aktor yang terlibat.

\section{WILAYAH STUDI}

Terdapat 5 lokasi ruang hijau kota yang akan diteliti : parc de la Tête d'Or, Berges de Rhône et Saône, Parc de Gerland, Sargent Blandan dan îlot de Mazagran. Pemilihan lokasi penelitian

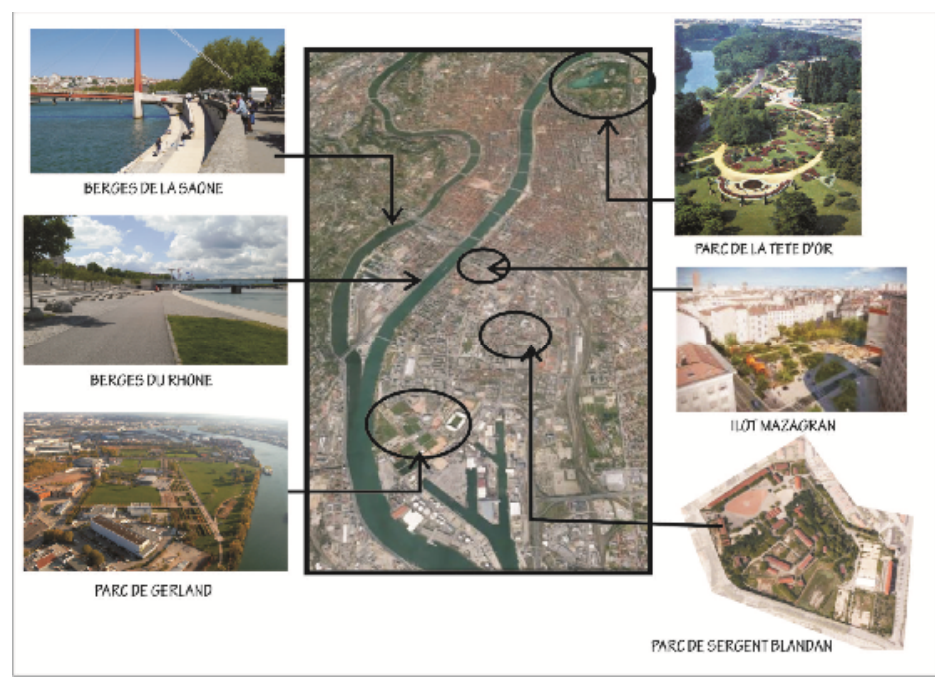

Sumber: GoogleEarth.com disesuaikan dengan kebutuhan penelitian yang mana mendasarkan 3 hal penting yang akan dicapai : pentingnya ruang hijau kota bagi masyarakat dan pemerintah, latar belakang penciptaan ruang hijau kota di awal tahun 1990an dan nilai-nilai masyarakat di ruang hijau kota, terutama yang berhubungan dengan partisipasi masyarakat. Selain itu, setiap ruang hijau kota memiliki alasan tersendiri dalam pemilihan menjadi obyek

penelitian. Le parc de la Tête d'Or merupakan hal yang penting untuk diikutsertakan mengingat taman tersebut

\section{LOKASI PENELITIAN}

merupakan taman yang paling tua dan paling luas di Lyon, atau dengan kata lain taman tersebut memiliki peran yang penting bagi Lyon. Kemudian untuk Parc de Gerland, Berges de la Saône et Berges du Rhône dan Parc Sergent Blandan, taman-taman tersebut merupakan perwakilan dari taman-taman yang diciptakan pada awal tahun 1990an. Sedangkan l'îlot Mazagran et le jardin des Amarantes, taman tersebut sangat penting mengingat terdapat proses partisipasi masyarakat yang kuat pada waktu proses penataan kembali taman tersebut.

\section{KAJIAN TEORI}

\section{Konsep pembangunan dan kota berkelanjutan}

Kondisi lingkungan yang buruk sebelum tahun 1990an menjadi pemicu lahirnya konsep pembangunan berkelanjutan. Tepatnya pada tahun 1992 pada konferensi di Rio de Janeiro, Brasil, aktor-aktor dunia yang menitikberatkan perhatian mereka pada permasalahan lingkungan berkumpul untuk berusaha menemukan resolusi permasalahan yang sedang berlangsung pada waktu itu. Pada pertemuan dunia tersebut, sebuah konsep pembangunan muncul yang secara prinsip berlandaskan pada 3 bidang terkait: lingkungan, sosial dan ekonomi. Konsep ini kemudian diberi nama konsep pembangunan berkelanjutan atau dalam bahasa aslinya Sustainable Development. 


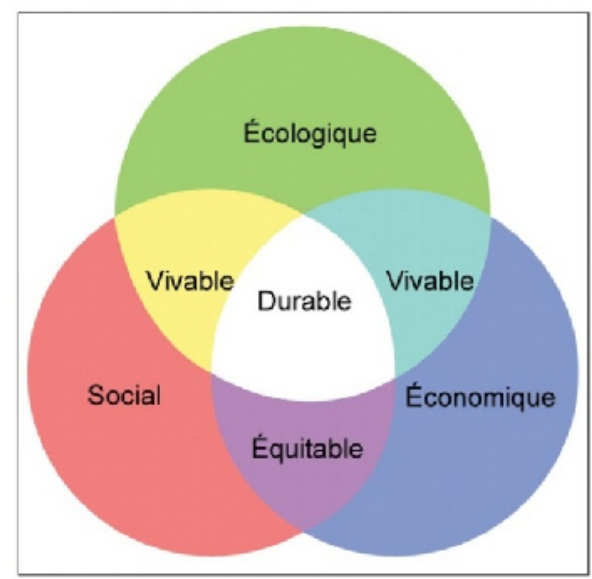

Sumber: GoogleEarth.com

GAMBAR 2

KONSEP PEMBANGUNAN BERKELANJUTAN

\section{Fenomena pemanasan kota/llot de Chaleur Urbain (ICU)}

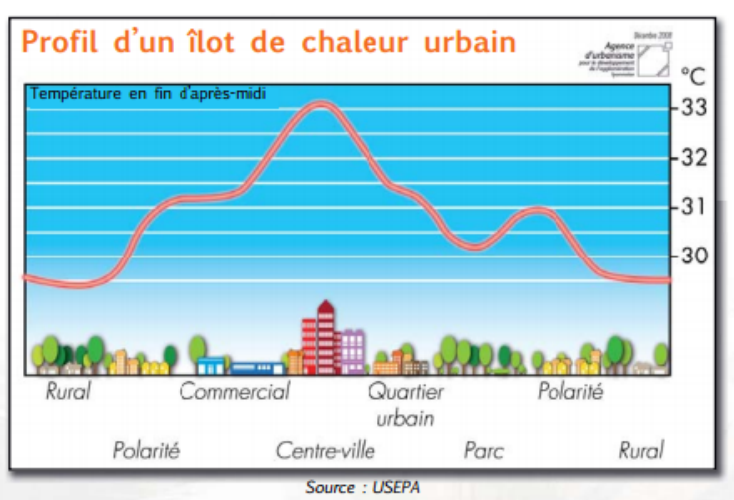

Sumber: Situs Resmi Grand Lyon,2010

Fenomena ini atau Urban Heat Island dalam bahasa inggris atau ICU (ilot de chaleur) dalam bahasa Prancis merupakan sebuah fenomena perkotaan yang mana terjadi perbedaan temperatur anatara kota dengan lingkungan sekitarnya. Temperatur kota cenderung lebih panas dari pada daerah yang mengitarinya. Menurut laporan yang terkumpul di situs resmi Grand Lyon, fenomena ini terjadi di Eropa sejak lama. Pada tahun 2003, terdapat banyak kematian

akibat fenomena pemanasan kota ini, sekitar 15 ribu kematian.

Urban Heat Island dipicu oleh banyak faktor, FENOMENA PEMANASAN KOTA

GAMBAR 3

FENOMENA PEMANASAN KOTA khususnya kurangnya ruang hijau kota dan daya serap tanah yang rendah yang disebabkan
oleh perubahan permukaan lahan kota, contohnya adanya perubahan fungsi lahan kota dari ruang hijau menjadi bangunan balok atau jalan (dari aspal atau beton) yang mana menyebabkan perubahan sensitifitas penyerapan cahaya atau panas matahari. Aspal dan beton merupakan elemen yang dapat menyimpan panas secara lama yang mana menimbulkan fenomena ini.

\section{Hubungan antara konsep kota berkelanjutan dengan ruang hijau kota}

Keberadaan ruang hijau kota adalah sebagai alat yang sangat penting untuk mendorong pengimplementasian konsep kota berkelanjutan, seperti yang telah disebutkan oleh banyak ahli perkotaan pada paragraf-paragraf sebelumnya. Mereka dalam penelitian mereka menunjukan bahwa adanya hubungan yang kuat antara konsep kota berkelanjutan dengan ruang hijau kota. Sebagai contoh, pepohonan dengan dedaunan yang hijau memiliki beragam manfaat bagi lingkungan, kota dan masyarakat: ruang hijau kota memiliki manfaat dalam 
fungsi sosial dan faktor psikologis masyarakat (Roovers, P., Hermy, M., Gulinck, H., 2002). Lebih lagi mengenai aspek sosial, berkat aksesbilitas yang gratis terhadap ruang hijau kota dan diperuntukan untuk masyarakat, ruang hijau kota menawarkan secara tidak langsung kesejajaran (égalité) sosial untuk masyarakat. Karena alasan tersebut, ruang hijau kota membawa kontribusinya pada aspek sosial pada konsep kote berkelanjutan dimana «sans la réduction des inégalités sociales et territoriales, il ne peut y avoir de développement durable dans nos villes et nos agglomérations » ( Louis Lévêque, ville de Lyon et Président du CR-DSU) yang mana berarti bahwa tanpa adanya egalitas sosial, tidak akan dapat terjadi pembangunan yang berkelanjutan di suatu wilayah.

Pada aspek ekonomi, ruang hijau kota yang dirawat dengan baik akan dapat meningkatkan nilai-nilai perkotaan. Ruang hijau kota dapat menarik masyarakat yang tinggal di pinggir kota atau uburban untuk datang dan menetap di dalam kota yang mana kemudian akan berdampak pada naiknya pendapatan kota dari pajak yang diterima dari kehadiran masyarakat tersebut (Monsieur Daniel Boulens auprès l'entretien, 2014). Lebih lagi, kota dapat menjadi tempat yang baik bagi para investor untuk menanamkan modal mereka yang mana secara langsung dapat berimbas pada perkembangan bisnis di dalam kota tersebut dan juga, para investor nantinya akan juga dapat membuka lapangan kerja bagi masyarakat kota. Tetapi, sebaliknya, riuang hijau kota daapt juga memicu tingginya harga lahan yang mana akan memunculkan permasalahan pembahuran masyarakat atau social mixation. Hal tersebut terjadi karena lahan yang tinggi nilainya hanya dapat dimiliki oleh masyarakat yang mampu, sedangkan yang tidak mampu akan mengalami kesulitan untuk hidup di dalam kota.

\section{ANALISIS PENELITIAN}

\section{Apa arti penting ruang hijau kota bagi masyarakat?}

Dari hasil analisis wawancara yang dilakukan kepada beberapa pengguna taman yang dibedakan menurut kriteria-kriteria tertentu, hasil ini dapat dilihat dari aspek sosial. Hal ini disebabkan bahwa aspek sosial sangat dapat dirasakan secara langsung oleh masyarakat.

Ruang hijau kota memiliki peran yang besar terhadap masyarakat, khususnya pada aspek sosial masyarakat. Dapat digeneralisir bahwa keberadaan ruang hijau kota merupakan ruang yang simpel atau sedehara tetapi memiliki fungsi yang sangat penting. Bagi masyarakat, ruang hijau kota yang didesain dengan baik dan dirawat dengan baik akan menyediakan suatu ruang beraktivitas yang nyaman yang dapat dimanfaatkan untuk berbagai kegiatan yang mendorong terciptanya fungsi kesehatan, kehidupan pribadi dan kehidupan sosial.

Salah satu contoh nyata manfaat ruang hijau kota bagi masyarakat adalah terciptanya pembahuran sosial atau dalam bahasa prancisnya disebut dengan istilah mixité sociale. Fenomena ini didorong dengan adanya pertemuan-pertemuan antara masyarakat di ruang hijau kota yang mana masyarakat tentunya berasal dari tempat dan bahkan latar belakang yang berbeda. Seperti penjelasan Daniel. Boulens mengenai pembahuran masyarakat, dia menjelaskan bahwa di ruang hijau kota Lyon, seperti taman Tête d'Or dan sisi sungai Rhône dan Saône, dapat ditemukan berbagai aktivitas yang dapat membantu terciptanya pembahuran masyarakat. Selain itu, sebagai contoh dari pembahuran masyarakat di ruang hijau kota, dapat dilihat dari pembahuran masyarakat di taman Mazagran. Apa yang teridentifikasi mengenai pembahuran masyarakat di taman Mazagran, banyak masyarakat datang dari latar belakang yang berbeda: wilayah asal, status sosial dan pekerjaan. Merek aberpartisipasi pada acara-acara yang diselenggarakan oleh asosiasi Brind'Guil. Daniel Boulens 
menambahkan bahwa pembahuran masyarakat dapat membawa banyak manfaat bagi kehidupan sosial masyarakat. Pembahuran masyarakat dapat menghindarkan masyarakat dari berbagai konflik sosial antar masyarakat dan dapat juga memperbaiki kehidupan sosial mereka. Hal tersebut disebabkan karena adanya pertukaran pengetahuan, budaya, pemikiran dan pengalaman diantara masyarakat

Tetapi perlu diperhatikan juga bahwa perbedaan yang terlalu signifikan antara masyarakat tidak akan dapat membantu terciptanya pembahuran masyarakat. Hal ini tentu saja jelas bahwa perbedaan yang terlalu redikal akan membawa suatu konflik antar masyarakat. Hal ini terlihat dalam observasi lapangan, meskipun tidak terlalu detail dalam menelitinya, adanya pengelompokan masyarakat tertentu dan tidak terlihatnya pembahuran masyarakatmasyarakat tertentu, seperti adanya usaha untuk saling menghindari antar suatu kelompok masyarakat yang memiliki perbedaan yang sangat tinggi dan komplek.

Bila dihubungkan dengan teori tentang kesehatan dan psikologi, keadaan atau aktivitas yang dilakukan oleh masyarakat di ruang hijau kota tidak hanya diperuntukan untuk mereka yang sedang mengalami stres dan bosan, tetapi untuk anak-anak yang membutuhkan suatu tempat bermain bersama teman-teman mereka. Dengan bermain di arena permainan, moril dan psikologis anak-anak akan menjadi lebnih baik, khususnya menyangkut dengan kebahagiaan mereka. Lebih lagi, tempat ini dapat menjadi tempat dimana anak-anak dapat menignkatkan dan mempererat hubungan mereka dengan teman mereka dan juga dengan keluarga mereka. $\mathrm{Hal}$ ini sangat baik untuk perkembangan mereka secara mental dan psikologi (Wells \& Evans, 2003 dan Cornell and Hadley, 2001).

Kemudian bagi masyarakat lainya yang mana berelaksasi di ruang hijau kota, seperti di tepi sungai Saône dan Rhône, sedikit banyak ruang hijau yang nyaman dan tenang itu dapat membantu untuk merefresh pikiran masyarakat serta menurunkan tingkat ketegangan dan stress yang mereka miliki. Sebagai tempat berkumpul, ruang hiaju kota juga meningkatkan integritas antara masyarakat. Abada (2007) mengungkapkan bahwa "The lack of integration may contribute to feelings of hopelessness, thus increasing the risk of depressives symptom ». Ungkapan tersebut dapat diartikan bahwa kurangnya integristas dapat berkontribusi terhadap perasaan putus asa yang kemudian dapat meningkatkan resiko despresi. Secara teori, bagi mereka yang telah bekerja, hal ini dapat membantu dalam meningkatkan produktivitas kerja mereka.

Di lihat dari sisi manfaat pendidikan, ruang hijau kota yang menyediakan manfaat ini hanyalah ruang hijau kota Tête d'Or. Hal ini disebabkan oleh fasilitas yang melengkapi taman kota ini. Dapat ditemukan berbagai fasilitas yang dapat menyalurkan pengetahuan, seperti kebun binatang, taman botani dan taman mawar.

Taman botani menjadi taman yang menarik, khususnya untuk mereka yang suka mengeksplor tentang keanekaragaman hayati : jenis-jenis atau spesies tumbuhan. Dengan akses yang gratis bagi seluruh pengunjung, taman ini dapat diakses secara mudah oleh mereka. Adanya papan informasi yang memberikan penjelasan mengenai ragam tumbuhan yang ada menjadi suatu hal penting yang dapat mempermudah terjadinya penyaluran pengetahuan ke pengunjung.

Di taman mawar, hal serupa juga terjadi. Hanya bedanya bahwa taman mawar berada di luar ruangan sedangakan taman botani berada di dalam ruangan. Keanekaragaman jenis mawar ditampilkan pada suatu papan informasi yang mana nantinya dapat memberikan informasi yang jelas kepada pengunjung. 
Untuk manfaat pendidikan yang terjadi di kebun binatang, secara umum sama dengan apa yang terjadi di taman botani dan juga taman mawar. Hanya saja, jenis pengetahuan yang ditawarkan berbeda, berupa keanekaragaman hewan. Proses pentransferan ilmu serupa dengan taman-taman sebelumnya, melalui papan informasi yang memberikan detail mengenai hewan yang tersedia di kebun binatang tersebut.

Di samping manfaat sosial dan pendidikan, ruang hijau kota, menurut pandangan masyarakat juga memberikan manfaat kesehatan untuk mereka, meskipun hasil ini tidak ditampilkan secara statistik kesehatan, hanya sebatas deskripsi singkat dari masyarakat. Banyak dari masyarakat yang memanfaatkan taman kota sebagai tempat favorti mereka untuk berolahraga, khususnya jogging. Sering sekali terlihat bahwa masyarakat memanfaatkan tepi sungai Rhône dan Saône, taman Tête d'Or, Gerland dan Sergent Blandan sebagai tempat mereka berlari. Hal tersebut dikarenakan adanya fasilitas untuk berlari, yaitu jalur pejalan kaki. Tetapi, tidak hanya jogging saja yang biasanya mereka lakukan, khusunya di taman Gerland, masyarakat dapat bermain tenis, sepak bola dan lain sebagainya. Sementara untuk di Sergent Blandan, masyarakat dapat bermain skateboard, bola basket, badminton, fitnes, futsal dan lain sebagainya.

Mengenai tingkat partisipasi masyarakat di proyek ini, yang harus ditekankan adalah sejarah berdirinya ruang hijau kota ini, termasuk adanya konflik kepemilikan lahan antara pemerintah kota Lyon dengan masyarakat yang bertempat tinggal di sekitar ruang hijau kota ini. Dari tahun 2003, mereka secara bergotong-royong membvangun taman kecil yang dipergunakan untuk mereka, utamanya untuk tempat berkumpul dan berkebun. Hingga 5 tahun kemudian, tepatnya pada tahun 2008, pemerintah kota Lyon memiliki inisiatif untuk mengolah kembali tanah tersebut. Dari sini lah terjadinya konflik antara mereka yang mana masyarakat mengklaim bahwa tanah tersebut adalah tanah mereka meskipun secara resmi, tanah tersebut adalah tanah miliki pemerintah kota Lyon. Selama bertahun-tahun, hal tersebut memunculkan rasa kepemilikan (sense of belonging) di sisi masyarakat atas tanah tersebut. Hal ini ditekankan oleh Lionel Perrin yang mengatakan bahwa masyarakat secara perlahan mulai terikat atas taman kecil ini. Masyarakat telah menganggap tempat ini sebagai tempat penting yang mana digunakan sebagai tempat untuk melakukan berbagai kegiatan di sela-sela kesibukan mereka dan juga, sejak 2003, mereka secara bersama-sama telah membangun taman ini tanpa adanya campu tangan pemerintah sedikitpun

Selain adanya faktor sejarah, dapat dilihat bahwa dengan adanya pengetahuan yang baik dari masyarakat terhadap pentingnya ruang hijau kota menjadi juga faktor yang mana mendorong masyarakat untuk berpartisipasi dalam proyek tersebut. Seperti yang diungkapkan beberapa masyarakat yang terlibat dalam proyek tersebut, mereka menganggap bahwa taman kota itu merupakan bagian penting yang harus ada di lingkungan mereka. Merekapun juga memberikan berbagai macam pendapat mereka mengenai manfaat ruang hijau kota. Oleh karena pentingnya ruang hijau kota tersebut, mereka ikut berpartisipasi untuk dapat menyalurkan pendapat dan pemikiran mereka di proyek tersebut yang mana juga menentukan masa depan wilayah mereka.

Tidak hanya kedua faktor tersebut yang mempengaruhi tingginya tingkat partisipasi masyarakat, tetapi dengan adanya sistem pemerintah yang baik yang mana mendukung terciptanya proses partisipasi masyarakat menjadi suatu faktor lain yang mendukung terciptanya proses partisipasi masyarakat yang tinggi. Tanpa adanya sistem partisipasi yang baik dari pemerintah, tidak akan ada jalan bagi masyarakat untuk dapat berpartisipasi dalam kegiatan-kegiatan pemerintah. 


\section{Apa arti penting ruang hijau kota bagi pemerintah ?Munculnya ruang hijau kota Lyon mulai pada tahun 19g0an}

Menurut artikel yang diambil dari l'atelier sur l'aménagement, la gestion publique des espaces verts et la politique de protection et de développement de l'arbre, sejarah ruang hijau kota dimulai pada pertengahan abad 19. Pada abad tersebut, pemerintah kota telah memberkan sebuah fokus yang besar pada pentingnya pepohonan di ruang kota. Ruang hijau kota dilihat sebagai salah satu dari bagian integral dan penting untuk terciptanya keseimbangan pembangunan kota. Hal ini bertujuan untuk menjadi sebuah elemen pelindung sinar matahri dan angin dan juga untuk berperan secara aktif dalam sistem irigasi dan drainase. Pephonan terintegrasi dilibatkan dalam komposisi kota. Hingga pada saat itu, kota-kota berbentuk kecil dan padat dengan ruang hijau yang tersebar di luar kota tersebut. Salah satu contoh pentingnya ruang hijau kota adalah pembuatan parc de la Tête d'Or pada tahun 1856 dan juga adanya penanaman pohon-pohon sejajar di pinggir aliran sungai dan canal di kota.

Akan tetapi, mulai pada abad 20, nilai-nilai penting dari ruang hijau kota menjadi hilang. Kotakota telah memasuki era dimana mobil-mobil telah masuk kota (démocratisation des voitures). Dikarenakan era ini, terjadilah perubahan besar dari fungsi peohonan dan ruang hijau kota dan lebih lagi, keberadaanya dikorbankan untuk keberadaan mobil di tengah kota. Lahan-lahan hijau kota dianggap sebagai sebuah kesempatan besar untuk dapat membuat perluasan jalan dan jalan tol. Dikarenakan oleh masalah ini, Lyon, dari tahun 1857 hungga akhir abad 20, tidak memiliki rencana pembuatan atau perbaikan kualitas kota melalui keberadaan ruang hijau kota.

Di antara tahun 1980 dan 1990, pemerintah kota Lyon telah mempertimbangkan kembali pentingnya ruang hijau kota. Hal ini disebabkan oleh apa yang terjadi di awal abad 20, permasalahan démocratisation de voiture dan perubahan fungsi ruang hijau menjadi jalan kota. Dapat dikatakan bahwa pada saat itu sedang terjadi apa yang disebut dengan krisis lingkungan. Fokus pada tahun 1980 ini ditandai dengan munculnya konsep-konsep dan undang-undang yang mendukung terciptanya kembali kondisi yang baik di sektor lingkungan.

Pada awal tahun 1990, mulai adanya kemunculan-kemunculan usaha pemerintah untuk menyelesaikan permasalahan lingkungan di lingkungan perkotaan. Kemudian, pemerintah kota berusaha untuk mengintegrasikan permasalahan ruang hijau kota pada strategi pembangunan aglomerasi. Pada saat itu, salah satu usaha pemerintah untuk lingkungan adalah dengan adanya kemunculan prototype dari konsep quartier durable.

Kemunculan usaha lokal ini secara tidak sengaja muncul bebarengan dengan adanya konferensi dunia di Rio pada tahun 1992. Pada konferensi itu, ahli-ahli perkotaan dan lingkungan dunia berkumpul untuk menyetuskan konsep pembangunan berkelanjutan. Tahun itu menjadi titik awal pelaksanaan sebuah cara baru dalam pembangunan melalui konsp pembangunan berkelanjutan.

Pada tahun 1992, setelah kemunculan niat baik pemerintah untuk lingkungan perkotaan, Lyon menjabarkan usaha-usaha tersebut pada teks atau artikel dengan publikasi dari la première charte écologique du Grand Lyon: la charte écologique urbaine (1992/1997), memungkinkan sebuah pertimbangan dari dimensi lingkungan dan politik atau kebijakan lokal. Dikumen ini ditekankan pada pentingnya ruang hijau kota dan ruang natural di pembangunan perkotaan. Setelah periode tersebut, yaitu peride kelahiran konsep pembangunan berkelanjutan, muilai adanya kemunculan dokumen-dokumen untuk membantu tujuan dalam pelaksanaan dan 
pengimpplementasian ruang hijau kota : kemunculan konsep kota berkelanjutan pada skala eropa (1994), le SCOT (alat konsepsi dalam pelaksanaan sebuah perencanaan strategis antar wilayah dari berbagai skala kota di bawah acuan dari projet d'aménagement et de développement durable (PADD)) (2000), le Tram Vert ainsi que le Tram Bleu (jaringan yang terbentuk untuk keberlanjutan ekologi melalui skema régionaux de cohérence écologique (SRCE) dan juga melalui dokumen-dokumen kota, kolektivitas wilayah, dan lain sebagainya (article R. 371-16 ducode de l'environnement) (1990), HQE (Haute Qualité Environnementale) (La haute qualité environnementale des bâtiments adalah sebuah konsep yang muncul pada awal tahun goan yang kemudian berkembang dan sekarang, menjadi pusat pergerakan yang penting mengenai bangunan di seluruh dunia), etc.

Daniel Boulens menambahkan dalam wawancaranya bahwa «il y a une transformation de mentalité des habitants et de la municipalité par rapport à leur manier de voir un développement urbain ", yang berarti bahwa adanya perubahan mental masyarakat dan pemerintah kota mengenai cara mereka melihat pembangunan perkotaan. Setelah tahun 1992, berkat kemunculan konsep pembangunan berkelanjutan, penciptaan ruang hijau kota menjadi cara politik dan pembangunannya mulai meningkat sedikit demi sedikit. Daniel Boulens menambahkan bahwa masyarakat mulai untuk mempertimbangkan pentingnya lingkungan, khususnya pada permasalahan perkotaan mereka: sosial, lingkungan dan ekonomi, serta, pemerintah prancis, diikuti oleh pemerintah kota Lyon mulai untuk memprogram aksi-aksi untuk melaksanakan konsep pembangunan berkelanjutan di negara dan kota-kota mereka.

Konsep kota berkelanjutan atau pembangunan berkelanjutan memang merupakan faktor yang mempengaruhi munculnya ruang hijau kota di Lyon pada tahun 1990an awal. Tetapi, terdapat juga faktor lain yang mempengaruhinya, seperti permasalahan yang munvul pada abad $20 \mathrm{di}$ kota Lyon.

Julien Singer pada waktu wawancara menyatakan bahwa «la différence du nombre de la création d'espace vert urbain lyonnais n'est pas provoqué seulement par le concept de développement durable, mais aussi par l'acte ou la réglementation de la ville de Lyon en environ 1992 concernant sur l'environnement » yang berarti bahwa kemunculan ruang hijau kota tidak hanya disebabkan adanya kemunculan konsep pembangunan berkelanjutan tetapi adanya peraturan tentang lingkungan yang muncul pada awal tahun 1990an atau tahun 1992. Perlu diketahui bahwa munculnya peraturan tentang lingkungan itu juga diawali adanya perubahan bentuk kota yang terjadi pada awal abad 20 dan hal ini menjadi dasar dari permasalahan perkotaan pada akhir abad 20, sekitar tahun 1980an yang mana mendorong pemerintah untuk bertindak untuk memecahkan permasalahan kota ini.

Sebelum tahun 1980an, tepatnya pada era démocratisation de voiture, pemerintah terus berusaha untuk memudahkan masuknya mobil di tengah kota, seperti dengan pengorbanan ruang hijau kota yang dijadikan untuk jalan kendaraan dan juga pada tahun 1934 dan 1938, pemerintah membuat bermacam-macam undang-undang yang memungkinkan kendaraan masuk ke kota : le décret du 19 avril 1934, le décret du 10 juillet 1935, le décret du 30 octobre 1935, le décret du 31 août 1937 dan le décret du 17 juin 1938 (Bibliothèque National de France (BNF), Bulletin des Lois de la République Française). Gambar di bawah ini menunjukan kondisi pemotongan pepohonan yang terjadi di tengah kota Lyon yang mana dikarenakan lemahnya perhatian pemernitah kota Lyon terhadap keberadaan ruang hijau dan pepohonan di tengah kota. 
Pada akhir abad ke 20, permasalahan kota menyangkut polusi udara, kendaraan, kemacetan dan lain sebagainya muncul. Pada tahun-tahun ini, pemerintah kota menyadari akan pentingnya suatu tindakan untuk menyelesaikan permasalahan ini, salah satunya dengan memunculkan kembali pentingnya ruang hijau kota di tengah kota Lyon.

Selain permasalahan démocratisation de voiture, terdapat pula permasalahan penduduk kota. Hal ini dijelaskan oleh Singer yang menjelaskan bahwa sebelum tahun 1992, Lyon memiliki sedikit sekali populasi. Terjadi juga permasalahan urban sprawl yang mana disebabkan karena masyarakat suka hidup dan bertempat tinggal dekat dengan alam yang mana kota tidak menawarkan lingkungan semacam itu pada periode tersebut. Oleh karena itu, pemerintah kota Lyon berusaha untuk memasukan unsur alam dengan pembangunan ruang hijau kota di kota Lyon.

Dari sisi pemikiran pemerintah, Daniel Boulens menyatakan bahwa « la création d'espace vert urbain joue un rôle important pour la ville et ses habitants. L'espace vert donne à la ville des grands avantages environnementaux grâce aux arbres, à la verdure et à tous les éléments verts. L'espace vert a un rôle social car c'est un lieu de rencontre, un lieu de jeux et d'activités très variées. En ce qui concerne l'économie, l'espace vert encourage la mise en valeur des quartiers et provoque l'arrivée de business ou d'investissement». Inti dari peryataan itu adalah bahwa ruang hijau kota itu memiliki fungsi yang penting untuk kota itu sendiri juga untuk masyarakat didalamnya, baik dari sisi lingkungan, sosial ataupun ekonomi.

Pada sisi lingkungan dari ke 5 ruang hijau kjota Lyon yang diteliti : les berges de la Saône, du Rhône, le parc de la Tête d'Or, le parc de Gerland dan le parc de Sergent Blandan, ruang hijau tersebut hampir memiliki struktur fisik yang sama, seperti vegetasi dan pepohonan, meskipun terdapat juga perbedaan fasilitas yang melengkapi ruang hijau tersebut, termasuk perbedaan fungsinya.

Dihubungkan dengan perubahan iklim, pemerintah kota Lyon memganggap bahwa ruang hijau kota juga memainkan peran penting di lingkungan perkotaan (AHTEG, 2009). Secara teori, menurut Cummins dan Jackson, vegetasi dapat menstabilkan suhu atau iklim di kota dan juga dapat menurunkan panas dan temperatur kota, mengurangi polusi udara dan mempengaruhi biodiversitas (Escobedo, Kroeger, \& Wagner, 2011; Groenewegen, vanden Berg, de Vries, \&Verheij, 2006). Lebih lagi, Daniel Boulens menambahkan bahwaterdapat peningkatan kualitas kota, beserta udaranya berkat kehadiran ruang hijau kota. Argumen Daniel Boulens ini didukung oleh suatu penelitian yang dilakukan di Beijing pada tahun 2013 yang mengemukakan bahwa ruang hijau kota memproduksi oksigen dan menyerap panas yang secara positif menyebabkan cooling effect di perkotaan. Sebagai tambahan, Daniel Boulens menambahkan bahwa «l'espace vert peut produire de l'oxygène grâce au processus de photosynthèse des arbres ». Intinya adalah bahwa ruang hijau dapat menghasilkan oksigen yang berguna bagi lingkungan kota berkat adanya proses fotosintesis pepohonan. Dia menjelaskan bahwa panas yang diserap melalui dedaunan dapat mengurangi intensitas panas matahari. Hal ini menciptakan suasana lingkungan yang segar dan nyaman, tetapi tentu saja hal ini tergantung pada luasan ruang hijau kota serta jenis pepohonan yang ada di ruang hijau tersebut.

Kemudian, hubungannya dengan dampak ruang hijau terhadap biodiversitas, Daniel Boulens mengungkapkan bahwa ruang hijau dapat menjadi ruang atau tempat tinggal bagi tumbuhan dan juga hewan. Seperti di Taman Tête d'Or yang mana telah ada dari abad 19 (1856), tumbuhan yang ada merupakan tumbuhan-tumbuhan lama atau tua. Hal ini merupakan salah satu contoh dari efek biodiversitas dari keberadaan ruang hijau kota. Keberadaan danau 
buatan dan juga kebun binatang juga melengkapi fungsi biodiversitasd dari ruang hijau ini. Tidak hanya di Tête d'Or saja, contoh efek biodiversitas juga dapat ditemkuan di taman Gerland dan Sergent Blandan yang mana didesain menyerupai alam bebas dengan hewan dan tumbuhan didalamnya. Selain itu, di sisi kanan dan kiri sungai Saône dan Rhône, dapat ditemukan juga berbagai hewan dan beranekaragam tumbuhan yang hidup. Sepanjang sungai ini merupakan tempat hidup tumbuhan dan hewan : bebek, serangga, burung, ikan, reptil, dan lain sebagainya. Di dekat wilayah Confluence, tepatnya di sepanjang tepi Jean-Jaques Rousseau, dapat ditemukan banyak sekali tumbuhan, yang mana kemungkinan besar diperuntukkan sebagai taman pasif (taman yang pembentukannya ditujukan dan ditekankan hanya untuk fungsi lingkungan, seperti mengkonservasi lahan, menyerap air dan lain sebagainya), untuk fungsi konservasi lahan di daerah tersebut.

Di sisi lain, ruang hijau kota menawarkan suatu fungsi untuk mengurangi permasalahan lingkungan perkotaan : polusi udara, longsor, penampung air dan penurunan temperatur kota. Pemerintah kota Lyon juga menyadari bahwa kehadiran ruang hijau kota berkontribusi juga pada hal-hal tersebut, khususnya polusi udara, meskipun hasilnya tidak terlalu signifikan bila hanya menghitung kadar polusi yang diserap oleh taman kota di Lyon saja. Seperti yang ditunjukan oleh Guillaume Bruyat (2011) pada penelitiannya, dia menyimpulkan bahwa pada sekala kota, hanya ada sekitar $1 \%$ penyerapan karbon oleh ruang hijau kota. Lebh luas lagi, menurut laporan penelitian Carbofor (Lousteau D. Coord., 2005), pada tahun 1996, seluruh hutan prancis hanya dapat menyimpan $1059 \mathrm{MtC}$ yang berarti hanya sebesar $1,7^{\wedge}$ dari penyimpanan dunia. Dua penelitian ini dapat menyimpulkan bahwa memang ada manfaat penyerapan karbon, tetapi jumlahnya sangat lemah.

Mengenai manfaat ruang hijau kota pada dimensi ekonomi kota, Daniel Boulens menyatakan bahwa ruang hiaju kota memiliki peran yang penting bagi perekonomian kota, khusunya pada harga lahan kota. Terdapat sekitar 20-30\% peningkatan nilai suatu wilayah yang mana terletak di dekat ruang hijau kota. Untuk mengilustrasikan, pada sebelum tahun 1856 , ketika belum ada taman kota Tête d'Or, haraga lahan di kawasan Masséna tidak terlalu mahal dibandingkan dengan kondisi sekarang yang mana kawasan tersebut menjadi salah satu kawasan dengan nilai lahan termahal di Lyon. Selain itu, dapat ditemukan juga sebagai komparasi, sebuah apartemen dengan spesifikasi yang sama dengan tipe T3, apartemen tersebut berharga 369.000 euro di dekat taman Tête d'Or dan berharga 299.000 euro yang terletah jauh dari taman kota. Memang perlu diingat, kehadiran ruang hijau kota bukan satu-satunya faktor dalam menentukan harga lahan. Masih ada beberapa faktor lain yang mempengaruhi harga lahan kota : jarak, transportasi kota, dsb (Wingo, 1960).

Berdasarkan teori pemasaran perkotaan atau marketing urbain, menurut Rosemberg (2000), kota berusaha untuk meletakkan dirinya di pasar perkotaan dengan menjual maige kota tersebut. Salah satu tujuan marketin urbain ini adalah untuk mengembangkan image kota. Singkatnya, marketing urbain menggunakan berbagai macam cara dan langkah untuk memperbaiki dan meningkatkan kualitas dan kopetitifan kota dalam persaingan antar kota. Jadi, ruang hijau kota bukan satu-satunya faktor untuk meningkatkan nilai jual kota, tetapi masih ada beberapa faktor lain yang ikut menjadi pengaruh peningkatan nilai jual kota.

Kemudian menurut Daniel Boulens, peningkatan nilai kota memunculkan efek ganda bagi kota. Hal ini dijelaskanya secara singkat bahwa investasi akan datang bila kota memiliki wajah yang cantik serta kualitas yang baik. Penanam investasi akan membuka lapangan kerja yang mana akan menyediakan lapangan kerja untuk penduduk kota pada khususnya. Selanjutnya, akan 
ada peningkatan pendapatan kota akibat efek ini melalui pajak dan pengeluaran masyarakat yang dihabiskan di kota.

\section{KESIMPULAN}

Konsep pembangunan berkelanjutan, permasalahan kota yang terjadi di abad 19 dan kerelaan dan kesadaran (political willingness) pemerintah menjadi 3 kunci utama pembangunan ruang hijau kota di awal tahun 1990an di kota Lyon.

Konsep pembangunan berkelanjutan yang muncul pada tahun 1992 menjadi arahan bagi negara yang menandatangani konsep tersebut dalam pembangunan kota mereka, termasuk Prancis. Kota Lyon berusaha untuk menerapkan konsep tersebut mulai tahun 1992. Tetapi, konsep ini tidak menjadi satu-satunya alasan pembangunan ruang hijau kota di Lyon di awal tahun 1990an, tetapi masih ada 2 faktor lainya yang berpengaruh.

Tampaknya, permasalahan yang terjadi sepanjang awal abad 20 berkontribusi juga dalam pembuatan ruang hijau kota di awal tahun 1990an. Permasalahan démocratisation de voiture dan juga urban sprawl menjadi permasalahan utama kota Lyon pada saat itu. Lebih parah lagi, pemerintah kota merubah pola pikir mereka pada saat itu untuk mengalihfungsikan penggunaan lahan hiaju untuk kepentingan kendaraan di dalam kota. Dikarenakan permasalahan-permasalahan tersebut, tahun 1990 menjadi titik awal untuk pemerintah dalam meningkatkan concern mereka untuk memecahkan permasalahan perkotaan mereka.

Mulai dari tahun 1990an, pemerintah kota Lyon berusaha untuk menggarisbawahi pentingnya ruang hijau kota, khususnya pepohonan dan taman kota. Pemerintah kemudian membuat beberapa peraturan dan undang-undang yang memungkinkan realisasi proyek kota untuk mengurang permasalahn kota yang sedang terjadi di saat itu. Peraturan yang mereka ciptakan adalah seperti SCOT, Tram bleu dan Vert, dan lain sebagainya.

Jadi dapat disimpulkan bahwa ruang hijau kota muncul pada awal tahun 1990an disebabkan oleh 3 hal besar, yaitu konsep sustainable development, permasalahan kota pada abad 20 awal dan kerelaan atau wilingness dari pemerintah untuk mengurangi permasalahan perkotaan.

Dari hasil analisis arti penting ruang hijau kota bagi masyarakat dan pemerintah, dapat disimpulkan bahwa ruang hijau kota Lyon dianggap menjadi sumber manfaat untuk mereka, pemerintah kota Lyon dan masyarakat. Dilihat dari seluruh ruang hijau kota Lyon yang diteliti, mereka memberikan andil positif bagi pemerintah dan masyarakat, seperti dengan menyediakan tempat bagi masyarakat untuk melakukan berbagai kegiatan mereka : olahraga, sosial, berekreasi, dan lain sebagainya. Secara singkat, ruang hijau kota memberikan 3 manfaat sekaligus yang dilihat dari sisi ekonomi kota, sosial dan lingkungan.

Kemudian mengenai tingkat partisipasi masyarakat, dapat disimpulkan secara singkat bahwa tingginya tingkat partisipasi masyarakat pada proyek Mazagran tidak lepas dari :

a. Faktor sejarah taman Mazagran

b. Faktor pengetahuan masyarakat mengenai pentingnya ruang hijau kota bagi mereka

c. Faktor manfaat ruang hijau kota

d. Sistem pemerintah tentang partisipasi masyarakat 


\section{DAFTAR PUSTAKA}

Bishop, I.D., Ye, W.S., Karadaglis, C., 2001. Experiential approach to perception response in virtual worlds.Landsc. Plan. 54, 115-123.

Bougé, Felix. Projet de fin d'étude : Caractérisation des espaces verts publics e fonction de leur place dans le gradient urbain - rural, 2008-2009

Bruyat, Guillaume. 2011. Estimation de la masse de carbone stocké par les arbres de la communauté urbaine de Lyon ou comment adapter le zonage d'un PLU pour en faire un zonage de végétation. ENTPE.

Conway, H., 2000. Parks and people: the social functions. In: Woudstra, J., Fieldhouse, K. (Eds.), The Regeneration of PublicParks.

Ebrahimpour, Maryam, et al. Analyzing of Urban Green Space Development Process with Emphasis on Sustainable Principle. AJER Volume 2 Issue-4.p 113-119.

Fratini, Roberto etMarone, Enrico. 2011. Green Space in Urban Area: Evaluation Public Spending for Management of GUARA. IJEB Vol. 1. p 9-14.

Johnston, M., Shimada, L.D., 2004.Urban forestry in a multicultural society. Journal ofArboriculture 30, 185-192.

Kaplan, S., Kaplan, R., 1989.The Experience of Nature.A Psychological Perspective. Cambridge University Press, Cambridge, $340 \mathrm{pp}$.

Kaplan, R., 1983. The analysis of perception via preference:a strategy for studying how the environment is experienced.Landsc. Urban Plan. 12, 161-176.

Krisdianto et al. 2012. What Users Said about Urban Green Space: A Challenge for Building The Resilient City of Banjarbaru, Indonesia. International Journal of Development and Sustainability ISSN: 2168-8662 Vol. 1 Number 1. p 57-78.

Lousteau, D. coord. 2005. Projet CARBOFOR : Séquestration de carbone dans les grands écosystèmes forestiers en France. Quantification, spatialisation et impacts de différents scénarios climatiques et sylvicoles

Rosemberg, M. 2000. Le marketing urbain en question : production d'espace et de discours dans quatre projets de villes. Paris: Anthropos.

Schipperijn, Jasper et al. 2010. Factors influencing the use of green space: Results from a Danish nationalrepresentative survey. Elsevier: Landscape and Urban Planning 95. $\mathrm{p}$ 130-137.

Shah MdetAtikulHaq. 2011. Urban Green Spaces and an Integrative Approach to Sustainable Development. Journal of Environment Protection vol. 2.p 601-608.

Tagtow, R., 1990. The need for urban forests. Am. City County105, 74-75.

Ulrich, R.S., 1981. Natural versus urban sciences: somepsycho-physiologicaleffects. Environ. Behav. 13, 523-556.

Ulrich, R.S., 1984. View through a window may influence recovery room surgery. Science 224, 420-421.

\section{Buku}

Carr, Stepen. 1992. Public Space. Cambridge : Cambridge UniversityPress

CERTU. 2011. Aménager avec le végétal pour des espaces vert durable.

CERTU. 2000. La concertation en aménagement. Collection du CERTU.

Charlot-Valdieu, Catherine et Outrequin, Philippe. 2011. L'Urbanisme Durable : Concevoir Un Eco Quartier. Le Moniteur.

Chiara de, Joseph dan Koppelman.1975.Urban Planning and Design Criteria Second Edition. New York: Van NostrandRainhad Company.inc.

Erikson, Erik H. 1993. Childhood and Society. New York, NY: W. W. Norton \& Company.

Paquot, Thierry. 2009. L’Espace Public. La découverte. 
Sansot, Pierre. 1993. Jardins Publics. Edition Payot.

Dubost, Françoise. 1997. Les Jardins Ordinaires. L'Harmattan : Paris.

Tapie-Grime, Muriel, et al. 2010. Développement Durable et Démocratie Participative, La Dynamique Performative Locale. PUCA : Paris. 